\title{
Does gastric acid release plasma somatostatin in man?
}

\author{
M R LUCEY, J A H WASS, P D FAIRCLOUGH, M O'HARE, P KWASOWSKI, \\ E PENMAN, J WEBB, AND L H REES

\begin{abstract}
From the Departments of Gastroenterology, Endocrinology, Chemical Endocrinology, St Bartholomew's Hospital, London, Department of Biochemistry, University of Surrey, Guildford, Surrey, and the Department of Medicine, Queen's University, Belfast
\end{abstract}

SUMmarY Food and insulin hypoglycaemia raise plasma concentrations of somatostatin. Both also stimulate gastric acid secretion but it is not clear whether gastric acid itself has any effect on somatostatin secretion. We, therefore, studied the effect on plasma concentrations of somatostatin of infusion of $0.1 \mathrm{~N} \mathrm{HC1}$ into the stomach and duodenum of healthy subjects. Plasma somatostatin did not rise with a small dose of $\mathrm{HCl}$ given intragastrically $(15 \mathrm{mmol})$ or intraduodenally $(4 \mathrm{mmol})$. After an intraduodenal infusion of $60 \mathrm{mmol} \mathrm{HC} 1$ over 30 minutes, sufficient to reduce intraluminal $\mathrm{pH}$ to 2 , plasma somatostatin rose moderately in five subjects from a mean value $( \pm \mathrm{SEM})$ of $32 \pm 3 \mathrm{pg} / \mathrm{ml}$ to a peak at 10 minutes of $54 \pm 11 \mathrm{pg} / \mathrm{ml}$. It is concluded that: (a) intragastric acid infusions do not release circulating somatostatin in man; and (b) that intraduodenal acidification albeit at grossly supraphysiological doses is a moderate stimulus of plasma somatostatin release. Therefore, gastric acid is unlikely to be a major factor mediating postprandial plasma somatostatin release in man.

Somatostatin is a tetradecapeptide widely distributed in brain, gut, and pancreas of many species with the greatest abundance in stomach, duodenum and pancreas. ${ }^{12}$ When administered exogenously in pharmacological doses it has many inhibitory actions, both endrocrine and non-endocrine. ${ }^{3}$ We have shown that circulating concentrations of somatostatin rise in man after oral ingestion of a $\mathrm{meal}^{4}$ or individual nutrients, especially fat or protein,${ }^{5}$ and after insulin-induced hypoglycaemia. ${ }^{6}$ Both oral food and hypoglycaemia are stimuli of gastric acid secretion. ${ }^{7}$ It is possible that gastric acid is one factor stimulating somatostatin release. Somatostatin is a potent inhibitor of gastric acid secretion $^{8}$ and therefore may participate in a negative feedback loop.

The present study was designed to investigate whether intragastric or intraduodenal acid can release somatostatin into peripheral plasma in normal subjects.

\section{Methods}

SUBJECTS

Fourteen male volunteers, mean age 22 years (range

Address for correspondence: Dr M R Lucey, Liver Unit, King's College Hospital, Denmark Hill, London SE5 8RX.

Received for publication 10 February 1984
21-24 years) were within $10 \%$ of their ideal body weight and taking no medication. None had a history of endocrine, gastrointestinal or renal disease. After an overnight fast the subject was intubated by mouth with a fine bore flexible tube and its tip was positioned in the stomach or second part of duodenum under radiographic control. Two separate studies were conducted.

\section{INTRAGASTRIC INFUSION}

Six subjects each received on two separate occasions, an intragastric infusion of (a) $15 \mathrm{mmol} 0 \cdot 1$ $\mathrm{N}$ isotonic $\mathrm{HC1}$, and (b) a control intragastric infusion of $150 \mathrm{ml} 0.15 \mathrm{~N} \mathrm{NaC} 1$ each given over 30 minutes. Intragastric $\mathrm{pH}$ was continuously monitored during the infusions and up to 110 minutes thereafter by a $\mathrm{pH}$-sensitive radiotelemetry capsule tethered $5 \mathrm{~cm}$ beyond the distal aperture of the infusion tube. ${ }^{9}$ Experiments were performed in random order separated by at least one week.

INTRADUODENAL INFUSION

(a) Three subjects received on one occasion an intraduodenal infusion of $4 \mathrm{mmol} 0 \cdot 1 \mathrm{~N}$ isotonic $\mathrm{HC1}$ given over five minutes. (b) Five subjects were given $60 \mathrm{mmol} 0 \cdot 1 \mathrm{~N}$ isotonic $\mathrm{HC} 1$ over 30 minutes into the second part of the duodenum. 
Intraluminal $\mathrm{pH}$ was continuously monitored as described for intragastric infusions.

Blood was taken intermittently through an indwelling heparinised needle for estimation of plasma somatostatin, gastrin, pancreatic polypeptide, gastric inhibitory polypeptide and motilin. Samples for hormone estimation were taken into lithium heparin tubes containing $10000 \mathrm{KIU}$ aprotonin, centrifuged at $4^{\circ} \mathrm{C}$ and separated. The plasma was frozen immediately and stored at $-20^{\circ} \mathrm{C}$ until assay.

ASSAYS

Plasma somatostatin, ${ }^{10}$ gastrin, ${ }^{11}$ pancreatic polypeptide, ${ }^{12}$ gastric inhibitory polypeptide ${ }^{13}$ and motilin $^{14}$ were assayed by radioimmunoassay. Before assay somatostatin was extracted using Vycor glass; $\mathrm{I}^{125}$ tyrosine-somatostatin (4 pg/tube) was used as a tracer together with a highly specific rabbit antisomatostatin serum (final dilution $1: 150000$ ) which gave a sensitivity of $10 \mathrm{pg} / \mathrm{ml}$ plasma.

All subjects gave informed consent in writing. These studies were approved by the District Ethical Committee of St Bartholomew's Hospital.

\section{STATISTICS}

Results are expressed as mean \pm 1 SEM. Student's $t$ test for matched pairs was used and $p<0.05$ taken as significant.

\section{Results}

INTRAGASTRIC INFUSION

The basal intragastric $\mathrm{pH}$ was 2 and this did not alter during or after the infusion of acid alone or saline. Basal plasma somatostatin concentrations did not significantly differ in either the acid or saline experiments and plasma somatostatin concentrations did not rise with either infusion. Similarly, neither infusion elicited a significant change in serum gastrin concentrations.

\section{INTRADUODENAL INFUSION}

(a) Three subjects each received an intraduodenal infusion of $4 \mathrm{mmol} 0.1 \mathrm{~N} \mathrm{HC1}$ in five minutes. Intraduodenal $\mathrm{pH}$ fell in all during the infusion to a nadir of 2. In two subjects plasma somatostatin at five minutes was slightly raised compared with basal concentrations: 12 vs $19 \mathrm{pg} / \mathrm{ml} ; 12$ vs $18 \mathrm{pg} / \mathrm{ml}$; while concentrations were unchanged in the third. See Figure 1. Plasma somatostatin was not increased in any subject thoughout the remaining period of sampling. Plasma gastrin, pancreatic polypeptide, gastric inhibitory polypeptide and motilin were unchanged thoughout each experiment in all three subjects.

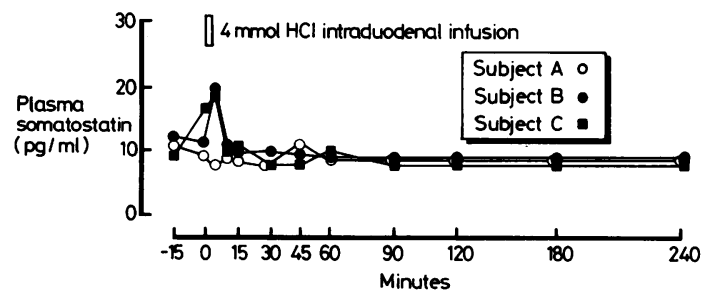

Fig. 1 Plasma somatostatin in three subjects given an intraduodenal infusion of $4 \mathrm{mmol} \mathrm{HC1}$.

(b) Five subjects each received an intraduodenal infusion of $60 \mathrm{mmol} 0 \cdot 1 \mathrm{~N} \mathrm{HC} 1$ over 30 minutes. See Figures $2 \mathrm{a}, 2 \mathrm{~b}$. Intraluminal $\mathrm{pH}$ fell immediately from a mean pre-infusion concentration of $6.9 \pm 0.4$ to a nadir of $2 \cdot 0 \pm 0 \cdot 1$ at two minutes and remained low thoughout the infusion. Intraluminal $\mathrm{pH}$ rapidly returned to its pre-infusion level when the infusion had been completed. Plasma somatostatin rose from a basal concentration $32 \pm 3 \mathrm{pg} / \mathrm{ml}$ to a peak of $54 \pm 11 \mathrm{pg} / \mathrm{ml}$ at 10 minutes ( $<<0.05 v s$ basal); and was significantly raised at 20 minutes $46 \pm 5 \mathrm{pg} / \mathrm{ml}$ $(\mathrm{p}<0.01)$ and 30 minutes $45 \pm 5 \mathrm{pg} / \mathrm{ml}(\mathrm{p}<0.01)$. Plasma somatostatin returned to basal concentrations by 40 minutes and gradually declined below basal concentrations thereafter.

Plasma gastrin, gastric inhibitory polypeptide and pancreatic polypeptide concentrations did not change during this infusion. Plasma motilin fell moderately during the acid infusion although this reduction reached significance at one time point only; basal $317 \pm 59 \mathrm{pg} / \mathrm{ml}, 247 \pm 57 \mathrm{pg} / \mathrm{ml}$ at 20 minutes $(\mathrm{p}<0 \cdot 05)$. Plasma motilin returned to preinfusion levels by 60 minutes after which it declined below basal concentrations.

\section{Discussion}

The present study was designed to investigate the potential role of gastric acid as a factor mediating the release of circulating somatostatin in man. Intragastric and intraduodenal infusion of $\mathrm{HCl}$ in dogs raises portal and peripheral plasma somatostatin and intraluminal somatostatin concentrations. ${ }^{15} 1617$ Somatostatin released into the local draining veins after intragastric instillation of a protein meal in dogs is enhanced by prior adjustment of the meal to a pH of $2 .^{18}$

In the present study plasma somatostatin concentrations were not significantly altered by either an intragastric infusion of $15 \mathrm{mmol} 0.1 \mathrm{~N} \mathrm{HC1}$ given over 30 minutes, a dose which mimics the estimated maximal postprandial gastric acid output ${ }^{19}$ or intraduodenal infusion of $4 \mathrm{mmol} 0.1 \mathrm{~N} \mathrm{HC} 1$ over five minutes, a stimulus reported to raise plasma concen- 

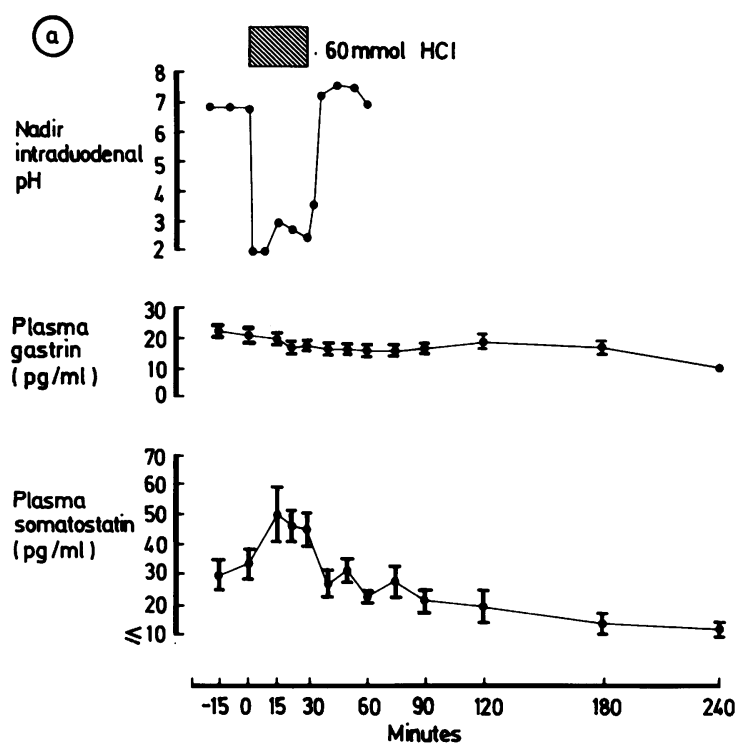
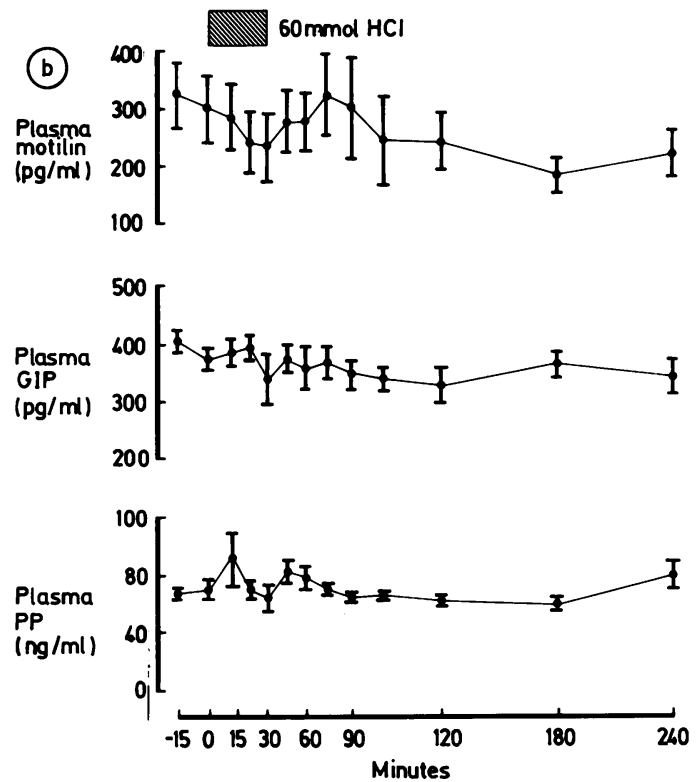

Fig. 2 (a) Intraduodenal $\mathrm{pH}$, plasma gastrin and plasma somatostatin in five subjects given an intraduodenal infusion of 60 mmol HCl. (b) Plasma motilin, pancreatic polypeptide, and gastric inhibitory polypeptide in five subjects given an intraduodenal infusion of $60 \mathrm{mmol} \mathrm{HCl}$.

trations of other putative gut hormones. ${ }^{20} 212223$ During an intraduodenal infusion of $60 \mathrm{mmol} 0 \cdot 1 \mathrm{~N}$ HC1 over 30 minutes, a grossly supraphysiological dose which caused a sustained reduction in intraduodenal $\mathrm{pH}$ not found distal to the duodenal bulb in healthy subjects, ${ }^{24}{ }^{25}$ there was a moderate rise in plasma somatostatin concentrations from $32 \pm 3 \mathrm{pg} /$ $\mathrm{ml}$ to a peak of $54 \pm 11 \mathrm{pg} / \mathrm{ml}$. This response should be compared with the effect of a 30 minute infusion into the second part of the duodenum of 100 calories of fat emulsion in normal subjects in which plasma somatostatin rose from a basal concentration of $30 \pm 3 \mathrm{pg} / \mathrm{ml}$ to a peak of $101 \pm 11 \mathrm{pg} / \mathrm{ml}$. $^{26}$ Thus we conclude that even grossly unphysiological duodenal acidification is a submaximal stimulus of plasma somatostatin. The failure to reproduce in man the effects on plasma somatostatin of intragastric and intraduodenal acidification found in dogs may be because of species variation and differences in assay technique. Furthermore, the increases in plasma somatostatin in dogs were most marked in local draining veins. Our studies are confined to the systemic circulation. The effects of acid on local somatostatin release in man may not be reflected in peripheral blood measurements. Nor do our studies gainsay the possibility that gastric acid has a permissive effect on somatostatin release to other stimuli such as food.

As intraduodenal acidification has been widely reported to stimulate the release of many other putative gut hormones in man, plasma gastric inhibitory polypeptide, pancreatic polypeptide and motilin were measured in addition to somatostatin and gastrin during the intraduodenal acidification experiments. Plasma gastric inhibitory polypeptide concentrations have been reported to be significantly increased after intraduodenal infusion of 5 mmol $0 \cdot 1 \mathrm{~N} \mathrm{HC1}$. Similar small doses of intraduodenal acid have been reported to raise plasma gastric inhibitory polypeptide, polypeptide and motilin concentrations in man. ${ }^{20} 2122$ It is surprising, therefore, that neither plasma gastric inhibitory polypeptide not polypeptide were significantly raised by either $4 \mathrm{mmol}$ or $60 \mathrm{mmol} 0 \cdot 1 \mathrm{~N}$ $\mathrm{HCl}$ infused into the duodenum. Furthermore, motilin concentrations showed a small but significant decrease during the infusion of the higher dose with a rebound to baseline concentrations when the intraduodenal $\mathrm{pH}$ had returned to 7 . The reasons for these discrepant results are not clear. The reported rise in pancreatic polypeptide with a small dose of intraduodenal acid was of very short duration. ${ }^{22}$ The gastric inhibitory polypeptide and motilin response previously described, however, were sustained. ${ }^{20} 21$ It may be significant that other workers have also failed to show an effect of intraduodenal infusion of $\mathrm{HC} 1$ on plasma gastric inhibitory polypeptide in normal subjects. ${ }^{2 f}$ They attributed this divergence 
to different antibody specificities. There can be no doubt that an adequate stimulus to lower intraluminal $\mathrm{pH}$ was given. The sustained albeit submaximal somatostatin response suggests that intraduodenal acidification did not simply damage the mucosa and thereby prevent all regulatory peptide responses.

The authors thank Dr A M Dawson for advice and encouragement, and $\mathrm{Mr} \mathrm{R}$ Colson for expert assistance. MRL and JW are supported by the Joint Research Board of St Bartholomew's Hospital. EP is supported by the Medical Research Council. The authors also thank the Peel Medical Research Trust.

\section{References}

1 Arimura A, Sato H, Dupont A et al. Somatostatin: abundance of immunoreactive hormone in rat stomach and pancreas. Science 1975; 189: 1007-9

2 Penman E, Wass JAH, Butler MG et al. The distribution and characterization of immunoreactive somatostatin in human gastrointestinal tract. Regul Pept 1983; 7: 53-65.

3 Wass JAH. Somatostatin, its physiology in man in health and disease. In: Besser GM, ed. Clinical neuroendocrinology, volume II. London Academic Press, 1982: 359-95.

4 Wass JAH, Penman E, Dryburgh JR et al. Circulating somatostatin after food and glucose in man. Clin Endocrinol 1980; 12: 569-74.

5 Penman E, Wass JAH, Medbak S et al. Response of circulating immunoreactive somatostatin to nutritional stimuli in normal subjects. Gastroenterology 1981; 81: 692-9.

6 Wass JAH, Penman E, Medbak S et al. Immunoreactive somatostatin changes during insulin-induced hypoglycaemia and operative stress in man. Clin Endocrinol 1980; 12: 269-75.

7 Grossman MI. Neural and hormonal stimulation of gastric secretion of acid. In: Code CF, ed. Handbook of physiology. Section 6: Alimentary canal, volume II. Secretion American physiological society, 1967: 83563.

8 Bloom SR, Mortimer $\mathrm{CH}$, Thorner MO et al. Inhibition of gastrin and gastric acid secretion by growth hormone release inhibiting hormone. Lancet 1974; 2: 1106-9.

9 Colson RH, Watson BW, Fairclough PD et al. An accurate, long term, $\mathrm{pH}$-sensitive radio pill for ingestion and implantation. Biotelemetry Patient Monit 1981; 8: 213-27.

10 Penman E, Wass JAH, Lund A et al. Development and validation of a specific radioimmunoassay for somatostatin in human plasma. Ann Clin Biochem 1979; 16: 15-25.

11 Yalow RS, Berson SA. Radioimmunoassay of gastrin. Gastroenterology 1970; 58: 1-14.

12 O'Hare MMT, Daly JG, Buchanan KD. Radio- immunoassay for pancreatic polypeptide and its relation to age. Clin Chem 1983; 29: 1923-7.

13 Morgan LM, Morris BA, Marks V. Radioimmunoassay of gastric inhibitory polypeptide. Ann Clin Biochem 1978; 15: 172-9.

14 Kwasowski P, Hampton GM, English J, Arendt J, Morgan LM, Marks V. Circadian Variations in plasma immunoreactive motilin. Regul Pept 1982; 4: 370.

15 Schusdziarra V, Harris VJ, Conlon MJ et al. Pancreatic and gastric somatostatin release in response to intragastric and intraduodenal nutrients and $\mathrm{HCl}$ in the dog. J Clin Invest 1978; 62: 509-18.

16 Uvnas-Wallensten $\mathrm{K}$. Effect of intraantral and intrabulbar $\mathrm{pH}$ on somatostatin-like immunoreactivity in peripheral-blood of conscious dogs. The possible function of somatostatin as an inhibitory hormone of gastric acid secretion and its possible identity with bulbogastrones and antral challone. Acta Physiol Scand 1981; 111 : 397-408.

17 Uvnas-Wallensten K, Efendic S, Johnson C et al. Effect of intraluminal $\mathrm{pH}$ on the release of somatostatin and gastrin into antral, bulbar and ileal pouches of conscious dogs. Acta Physiol Scand 1980; 110: 391-400.

18 Schusdziarra V, Rouiller D, Harris V et al. Gastric and pancreatic release of somatostatin-like immunoreactivity during the gastric phase of a meal. Effects of truncal vagotomy and atropine in the anaesthetized dog. Diabetes 1979; 28: 658-63.

19 Fordtran JS, Walsh JH. Gastric acid secretion rate and buffer content of the stomach after eating. J Clin Invest 1973; 52: 645-57.

20 Mitznegg P, Bloom SR, Domschke W et al. Release of motilin after duodenal acidification. Lancet 1978; 1: 888-9.

21 Ebert R, Illmer K, Creutzfeldt W. Release of gastric inhibitory polypeptide (GIP) by intraduodenal acidification in rats and humans and abolishment of the incretin effect of acid by GIP antiserum in rats. Gastroenterology 1979; 76: 515-23.

22 Hacki WH, Hatler F, Gyr K, Kayasseh L. Release of pancreatic polypeptide in man. Scand J Gastroenterol 1978; 13: suppl 49: 73.

23 Fahrenkrug J, Shaffalitzi de Muckadell O. Plasma secretin concentration in man. Effect of intraduodenal glucose, fat, amino acids, ethanol, $\mathrm{HC1}$, ingestion of a meal. Eur J Clin Invest 1977; 7: 201-3.

24 Rhodes J, Prestwich CJ. Acidity at different sites in the proximal duodenum in normal subjects and in patients with duodenal ulcer. Gut 1966; 7: 507-14.

25 Anderson S, Grossman MI. Effects of histalog and secretion on gastroduodenal profile of $\mathrm{pH}$, potential difference, and pressure in man. Gastroenterology 1966; 51: 10-7.

26 Lucey MR, Fairclough PD, Wass JAH et al. Response of circulating somatostatin, insulin, gastrin and GIP to intraduodenal infusion of nutrients in normal man. Clin Endocrinol 1984 (in press).

27 Burhol PG, Jorde R, Waldrum HL. Radioimmunoassay of plasma gastric inhibitory polypeptide (GIP), release of GIP after a test meal and duodenal infusion of bile and immunoreactive plasma GIP components in man. Digestion 1980; 20: 336-45. 